\title{
Financial Performance Role as Influence Mediation of Intellectual Capital on Company Value Listed on BEI of 2015-2017 Period
}

\author{
Mahanani Putraningrum*, Isnalita \\ Faculty of Economic and Business, Airlangga University, Jl. Airlangga No.4, Airlangga, Gubeng, Surabaya, \\ East Java, Indonesia
}

*Corresponding Author: Mahanani Putraningrum, Faculty of Economic and Business, Airlangga University, Jl. Airlangga No.4, Airlangga, Gubeng, Surabaya, East Java, Indonesia

\begin{abstract}
The objective of this research is to determine the influence of intellectual capital on company value with financial performance as an intervening variable. The samples used were companies listed on BEI with period 2015-2017. This study used a quantitative method by testing hypotheses using path analysis carried out through linear regression. Influence mediation was tested using the Sobel test. Results of regression and Sobel test results showed that the financial performance may mediate the influence of intellectual capital on company value.
\end{abstract}

Keywords: Financial performance, Firm value, Intellectual capital

\section{INTRODUCTION}

Intellectual capital is vital capital for company within current competition situation. Intellectual capital becomes the most crucial capital compared to financial and physical capital (Chen, Zhu \& Sie, 2004). Intellectual capital could create crucial business innovation in solving competitor and create barriers to entry for new competitor. As company could solve pressure from the existing as well as new competitors than it shall provide positive impact on company profitability level. Primary motivation that inspire company is maximum profitability to win competition. Profitability ratio is the most crucial financial ration as it represents company operational efficiency and serves as decision making basis for management and investor (Khalique, Nassir, Hasan, \& Narindah, 2013).

Company attention currently focused in knowledge asset as one form of intangible assets. Rupert (1998) in Sawarjuwono and Kadir (2003) stated that in knowledge-based management system, conventional capitals (financial resources, natural resources, and physical assets) become less important compared to knowledge and technology based capitals. Knowledge and technology utilization could benefit in efficient and economical other resources utilization for competitive excellence in the future.

According to RBV (Resources-Based View of Firm), company perceived as strategic resources. This theory requires company primary role of determining success through ability in transforming its knowledge as idea into knowledge form as strategic asset that could cause knowledge treated as primary target to manage, control, rationalize, and even calculate, that reflected in intellectual capital.

Several empirical studies verified intellectual capital influence on company value and financial performance. Pramelasari (2010) examined intellectual capital influence on company value and financial performance on companies listed in BEI of 2004-2008 period. Research showed that VACA had negative influence on company value, meanwhile two other components (VAHU and STVA) had positive influence. It suggests that company have capital employee that less likely to increase value. Meanwhile human capital and structural with high value could increase company value.

\subsection{Resources Based View of Firm (RBV)}

RBV (Resources Based View of Firm) theory initially emerged in 1959 pioneered by Penrose reaction from previous theory failure specifically Market Based View theory that described competitive strategic making focus placed on effort of protecting market, through creating barrier for competitor to experience difficulty in entering market. This perspective considered by various elements 
neglecting resources and interaction between resources and its activities as well (Sangkala, 2016). $\mathrm{RBV}$ becomes the most crucial approach in strategic management sector development, as it prefers potential in responding for question "Why do several companies more succeed than the others?"

RBV is conceptually resources that heterogeneously distributed cross company. This resources could not be transferred inter-company without charges, as company resources shall different across time. Resources could be in form of specific physical asset, for instance tools, human resources (skills), and organizational process (marketing). As company has valuable and scare resources, then company could create comparative excellence. These resources are unable to replicate and replace. Other resources deemed unable to provide similar function, then competitive excellence could be adjusted. RBV predicts structure that shall be selected in low opportunity condition if prediction provide more valuable knowledge to apply into company activities (Sangkala, 2006).

Perspective concerning knowledge as highly strategic company resources based on reality, that knowledge could meet criteria as resources usable resources to develop company competitive sense. According to Barney (1991), the following are requirements for resources to be deemed strategic:

- Valuable,

- Scare,

- Hard or impossible to imitate by competitor,

- Irreplaceable by other type/form of resources.

As knowledge meets above criteria, then it deemed as strategic resources. This theory requires company primary role of determining success through ability in transforming its knowledge as idea into knowledge form as strategic asset that could cause knowledge treated as primary target to manage, control, rationalize, and even calculate (Sangkala, 2006).

In connection with this research, RBV theory manifests in intellectual capital variable that is action from RBV theory through learning, for instance providing attention concerning how company learns, innovates, and diffuses technology. This research aimed to test intellectual implementation, whether by prioritizing leaning, innovation, technological diffusion as trademark intellectual capital, company shall excel in competition reflected on financial performance, that subsequently would influence company value (shares price).

\subsection{Signal Theory}

Signal theory based on assumption that information received by parties are not similar. In other words, Signal Theory related to information asymmetry. Information asymmetry occur between company management with company external party or investors is basic concept in developing signal theory. According to Jama'an (2008), reducing uncertainty concerning future company prospect.

Signal Theory initially described by Ackerlof, Spence, and Stigliz from United States of America and rewarded them with Economic Nobel in 2001. According to Ackerlof (1970), Signal Theory could be described with discrepancy between information sender and information recipient. Information sender party has superior position compared to information recipient party as they could determine what kind of information to inform, then perception could be manipulated. Spence (1973) in Marisanti (2012) in signalling theory stated that company with high performance could provide financial information to deliver signal into market.

According to Sharpe (1997: 211), accounting information announcement provides signal that company has good prospect in the future (good news) that investors interested in making shares trading, that therefore market would react that reflected through shares trading volume. Therefore relationship between information publication either financial statement, financial condition as well as socio-political and shares trading volume fluctuation could be observed in market efficiency.

\subsection{Intellectual Capital}

According to Stewart (1997) intellectual material are knowledge, information, intellectual property, and knowledge that could be used to generate "property". Ross et. Al (1997) stated that market value measurement influenced by tangible (financial capital) and intangible (intellectual capital). 
Roslender \& Fincham (2001) briefly identified intellectual capital as difference between company market value (company business) and company asset book value or its financial capital.

Intelelctual capital (IC) is not ordinary accounting concept (Mouritsen et al., 2001). It is not sufficiently stating that IC is difference between book value with company value. As company speaks about IC report, they actually express their interest in controlling and managing company. Practically, IC is concerning managerial activity attributable in effort in the name of knowledge. Such activities frequently related to employee development, organizational restructurisation, and marketing activity development.

\subsection{Intellectual Capital Development}

Intellectual capital theme is relatively new in Indonesia. Indonesian companies currently tent to use conventional based instead of knowledge based in developing their business. Strict globalization era competition demand company to immediately shift their business activity basis, that previously conventional based or physical based into knowledge based. Intellectual capital concept believed to have crucial role in current or future condition (Marzo, 2014). Its implication, demand concerning intellectual capital also increased alongside with increased research disclosing intellectual capital practice, considering its impact on competitive advantage on shareholders eyes.

\section{Intellectual Capital Development Chronology}

\begin{tabular}{|c|l|}
\hline Period & \multicolumn{1}{c|}{ Progress } \\
\hline $\begin{array}{c}\text { Early } \\
\text { Mid 1980s }\end{array}$ & $\begin{array}{l}\text { The emergence of common understanding concerning intangible value (ordinarily referred to } \\
\text { as "goodwill") }\end{array}$ \\
\hline $\begin{array}{c}\text { Enformation era took role, and gap between book value and market value more clear at several } \\
\text { companies }\end{array}$ & $\begin{array}{l}\text { Systematic initiation to measure and report company supply on intellectual capital into } \\
\text { external parties (for instance: Celemi and Skandia; SCSI, 1995) } \\
\text { In 1990, Skandia AFS assigned Leif Edvinsson as “Intellectual capital director. It was the first } \\
\text { time that intellectual capital management raised into formal position and obtained company } \\
\text { legitimation. }\end{array}$ \\
\hline Mid 1990s & $\begin{array}{l}\text { Nonaka and Takeuchi (1995) presented work extremely influence on “company knowledge } \\
\text { creation". Though this book concentrated on “knowledge” and intellectual capital this book } \\
\text { sufficiently demonstrated that they focused on intellectual capital. } \\
\text { In 1994, Skandia annual report supplement produced. This supplement focused on company } \\
\text { supply presentation and assessment on intellectual capital. Intellectual capital visualization } \\
\text { attracted other company interest to follow Skandia instruction. } \\
\text { Other sensation occur in 1995 when Celemi used knowledge audit to offer detail estimation on } \\
\text { intellectual capital statement. } \\
\text { Intellectual capital pioneers published sold-out books with intellectual capital topics (Kaplan } \\
\text { and Norton, 196; Edvinsson and Malone, 1997; Sveiby, 1997). Edvinssion and Malone paper } \\
\text { reviewed more concerning process and ,how“ intellectual capital measurement was. }\end{array}$ \\
\hline End of & $\begin{array}{l}\text { Intellectual capital became popular topics with researcher and academicians conferences, } \\
\text { working paper, and other publication finding audience. } \\
\text { Big projects total increase (for instance the MERITUM project; Danish; Stockholm) organized } \\
\text { with intention, amongst them, to introduce several research concerning intellectual capital. In } \\
\text { 1999, OECD organized international symposium concerning intellectual capital. }\end{array}$ \\
\hline
\end{tabular}

Source: Petty and Guthrie (2000) in Ulum (2016)

\subsection{Intellectual Component}

\subsubsection{Value Added Intellectual Coefficient - VAIC}

Pulic (in Ulum, 2007) created a measure to assess whether efficiency from added value as product of company intellectual ability (Value Added Intellectual Coefficient - VAIC). VAIC is not intended to measure intellectual capital value that company possesses; it is accounting tool to measure and monitor company physical capital performance and company intellectual capital performance represented by human capital and structural capital efficiency (Pulic, cited in Ulum, 2007). VAIC represents how both resources (physical capital and intellectual capital) have been efficiently utilized by company.

Pulic (1998) considered this method as universal indicator showing intellectual ability from business unit value creation ability and serves as business efficiency size in knowledge-based economic. The 
following are several reasons of using VAIC as indicator from intellectual capital (Pulic, cited in Firer and William, 2003):

- VAIC provides standardized and consistent basic in measurement that VAIC number is comparable between companies as it provides standard and consistency based on intellectual capital (IC) performance size.

- Data used in VAIC measurement is based on accessible data within financial report that has been audited and objective and reliable.

- This method implementation is simple and its result is interpretable. This is the most suitable method with internal as well as external stakeholder cognitive understanding.

\subsubsection{Value Added Capital Employed - VACA}

Pulic (in Firer \& William, 2003) assumed that if 1 unit of CE (Capital Employed) generated higher return than other company, it means that such company is better than using its CE. Value Added Capital Employed is company ability in managing capital asset resources as it it is well managed could increase company financial performance (Dewi, 2011).

\subsubsection{Value Added Human Capital - VAHU}

Value Added Human Capital (VAHU) represent how many VA could produce with funds for employee. Relationship between VA and HC indicated HC ability to create value within company. Steward (in Puspitasari, 2011) described that human capital is employee ability to process product well that it could reach consumer and consumer shall not shift into competitor. According to resource-based theory concept, in order to survive in competition, company requires excel human resources and good management on its human resources. Human resources or employee are company strategic asset that could increase company quality.

\subsubsection{Structural Capital Value Added - STAVA}

Structural Capital Value Added (STVA) is total of structural capital required to generate 1 rupiah from VA and is indicator of structural capital succeed in value creation (Ulum, 2007). According to Suwarjuwono (2003), structural capital is company ability in fulfilling company production process and its structure that support its employee to generate optimal intellectual performance and entire business performance, for instance: company operational system, manufacturing process, organizational culture, management philosophy and any form of intellectual capital that company possess and control.

\subsection{Intellectual Capital Role}

Intellectual capital has strategic role in every company. Intellectual capital enables company to develop its excellence sustainably from its knowledge-based activities, could adapt with environment need and demand, and able to perform its task and activitiy efficiently and effectively (Mulyadi, 2014).

\subsection{Intellectual Capital as Competitive Excellence}

Organizational internal strength source that might not be adapted by competitor is knowledge management. As previously outlined, knowledge exist on every individual and each individual has different knowledge one and another. Competitors are unlikely to imitate knowledge that company possess.

As valuable resources for organization, organization should manage knowledge well. Study carried out by Davenport et al. (1998) identified four steps organization must perform for intellectual capital turns into strategic strength.

\subsection{Financial Performance}

According to Mayanti (2009), company is one form of organization commonly has certain objective to attain in effort to meet its members interest. Succeed in attaining company goal is management achievement. Achievement or performance appraisal of a company measured as it could be made as decision making basic either for internal as well as external parties. 
Financial performance appraisal basis is financial report made according to generally accepted financial accounting principle (Sucipto, 2003), benefit of using accounting data is that accounting data serves as objective appraisal basis instead of subjective appraisal basis, that it is expected that financial performance appraisal result could be accepted by entire parties.

There are 2 (two) methods that could be used to appraise financial performance of company (Moneva $\&$ Ortas, 2009). The first method is market-based measure, such as shares performance, and others. Meanwhile the second method is accounting-based measures such as profitability, return on assets (ROA), asset turnover, and others. Financial performance appraisal method used in this research is accounting-based measures especially profitability, as it could reflect policy contribution that company make on financial succeed that constitutes company primary objective.

\subsection{Company Value}

Company is an organization combining and organizing various resources with intention to produce products and services to sell (Salvatore, 2005). Putra and Wirawati (2013) defined company value as description concerning company general condition, including financial information such as profitability and shares price. Investors use company value as standard of company, that frequently associated to shares price. High company value indicates high prosperity level as shareholders.

Hermuningsih (2013) supported that company value could be measured with price to book value (PBV), comparison between shares price with book value per share. Other relevant indicator is book value per share, comparison between common equity with outstanding shares (Fakhruddin and Hardianto, 2001). In this terms, PBV could be defined as comparison result between shares market price with shares book value. High PBV would increase market trust on company prospect and indicating high shareholders prosperity (Soliha and Taswan, 2002). PBV could also mean ration indicating whether traded shares price are overvalued or undervalued compared with such shares book value (Fakhruddin and Hadianto, 2001).

\section{CONCEPTUAL FRAMEWORK}

Thinking framework on research based on two fundamental theories, RBV theory stating that human resources potential utilization causing company excel in competition; and signal theory stating that good financial performance information provides message for investors to decide to invest their capitals in form of shares purchasing. These could be outlined in the following figure 2.1. below.

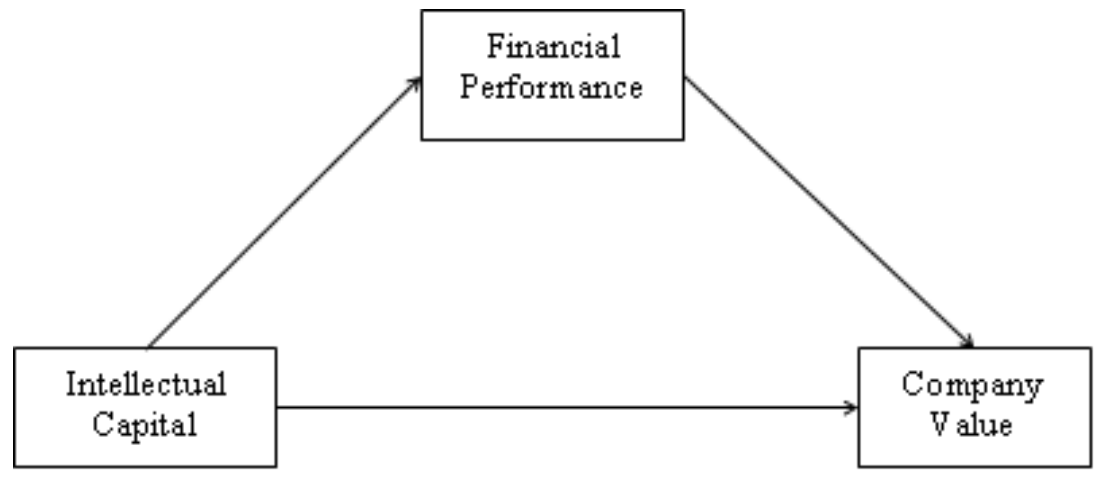

Figure2.1. Conceptual Framework

Chen et al. (2005) and Widarjo (2011) described that investors would provide higher value on company with higher intellectual resources than company with low intellectual resources as IC comprised of three inter-connected crucial components and synergistically form IC that shall increase company performance. Such value provided by investors into company shall be reflected in company shares price as investors would observe company performance and judge such company.

\subsection{Research Hypothesis}

Intellectual capital implementation could seriously and sustainably improve company financial performance. Through the possessed knowledge, experience, organizational technology, customer relationship, and professional skills could be established why it could increase financial performance. Ponpearchan (2016) research affirmed this statement. 
Subsequently, good financial performance informed in annual report shall be positively responded by investors by showing their interest to purchase shares, that shares price predicted to sustainably increase. Investors still certain that this year financial performance would reflect stable and sustainable business in future, therefore prosperity that investors attain shall be realized. Sucuahi \& Cambarihan (2016) and Ayuningtyas (2013) research supported that statement. Based on several empirical evidences above, the following is research hypothesis:

\section{H: Financial performances mediate Intellectual Capital influence on company value.}

\section{RESEARCH METHOD}

This research focused on empirical evidence seeking of intellectual capital implementation influence on company value through financial performance variable as intervening variable. According to previous theories and research, intellectual capital implementation through the possessed knowledge, experience, organizational technology, customer relationship, and professional skills activities believed to increase financial performance. Subsequently, impressive financial performance information, positively responded by investors that company values shall increase.

This research used quantitative method. This research analyzed numeral data (number) processed with statistical method by focusing on hypothesis testing supported by theories and facts.

\subsection{Variable Identification}

\subsubsection{Independent Variable}

This variable used one independent variable, namely intellectual capital.

\subsubsection{Dependent Variable}

In Indonesian Language, dependent variable frequently referred to as bound variable. It is variable influenced by or that becomes consequence, due to independent variable (Sugiyono, 2009:59). Dependent variable in this research was company value.

\subsubsection{Intervening Variable}

Intervening variable is variable connecting independent variable and dependent variable. Intervening variable in this research was financial performance.

Table3.1. Operational Variable Components

\begin{tabular}{|c|c|c|c|}
\hline $\begin{array}{l}\text { Variable } \\
\text { Status }\end{array}$ & $\begin{array}{l}\text { Variable } \\
\text { Name }\end{array}$ & Operational Definition & Measurement \\
\hline $\begin{array}{l}\text { Dependent } \\
\text { Variable }\end{array}$ & $\begin{array}{l}\text { Company } \\
\text { Value }\end{array}$ & $\begin{array}{l}\text { Market value reflecting } \\
\text { shareholders prosperity in } \\
\text { maximum if company shares } \\
\text { price increase (Retno and } \\
\text { Priantinah, 2012). }\end{array}$ & $\begin{array}{l}\frac{(\mathrm{EMV}+\mathrm{D})}{(\mathrm{EBV}+\mathrm{D})} \\
\text { EMV = Shares price value (close price } \mathrm{x} \\
\text { total shares issued) } \\
\text { EBV = Book value from total equity } \\
\mathrm{D}=\text { Book value from total debt }\end{array}$ \\
\hline $\begin{array}{l}\text { Independent } \\
\text { Variable }\end{array}$ & $\begin{array}{l}\text { Intellectual } \\
\text { Capital }\end{array}$ & $\begin{array}{l}\text { Company knowledge capital } \\
\text { measured with VAIC }\end{array}$ & $\begin{array}{l}\text { (VAIC }=\text { VACA+VAHU+STVA }) \\
\text { VAIC }=\text { Value Added Intellectual Capital } \\
\text { VACA }=\text { Value Added Capital Employed } \\
\text { VAHU = Value Added Human Capital } \\
\text { STVA }=\text { Structural Capital Value Added }\end{array}$ \\
\hline $\begin{array}{l}\text { Intervening } \\
\text { Variable }\end{array}$ & $\begin{array}{l}\text { Financial } \\
\text { Performance }\end{array}$ & $\begin{array}{l}\text { Company ability in generating } \\
\text { profit. Is one of accounting-based } \\
\text { financial performance judgment } \\
\text { (Orlitzky et al, 2003), that } \\
\text { commonly informed by company } \\
\text { in annual report. }\end{array}$ & $\frac{\text { Net Profit }}{\text { Sales }}$ \\
\hline
\end{tabular}

Source: Various sources

\subsection{Data Collection Method}

This research used documentary method in data collection according to Bungin (2009:144) documentary method is principally method used to track historical data. In this research, most of data 
were in form of report, either financial report (to discover financial performance measure using ROA and intellectual capital) and company annual report (to discover shares closing price).

\subsection{Data Source and Type}

Data source used in this research were secondary data using documentation data, specifically data collected from library, books, and internet. Data type in this research were quantitative data. In addition, this research also used data in form of financial report and annual report collected from www.idx.co.id of 2015-2017 period.

\subsection{Population and Sample}

Populations are region comprised of object or subject with certain stipulated quality and characteristic to learn and to be drawn conclusion from (Sugiyono, 2011:80). Sample is subset from population unit (Bungn, 2009:118). Research selection carried out using purposive sampling method. Purposive sampling is sample determination technique with certain considerations (Anshori \& Iswati, 2009:105). The referred considerations are presented in table 3.2.

Table3.2. Sample

\begin{tabular}{|c|l|c|}
\hline 1 & Companies which data could be accessed in Indonesian Stock Exchange of 2015-2017 period & 948 \\
\hline 2 & Which annual report did not inform required data & $(213)$ \\
\hline \multicolumn{2}{|l|}{ Total Population with ready-processed data } & 735 \\
\hline
\end{tabular}

\subsection{Analysis Technique}

\subsubsection{Path Analysis}

Path analysis required to discover whether a variable could mediate relationship between independent and dependent variable. Path analysis uses regression analysis to estimate causality relationship between stipulated variables (Ghozali, 2009). In this research, path analysis could be described with the following equation:

$$
\begin{aligned}
& \mathrm{KK}=\alpha+\beta_{1} \mathrm{IC}+\mathrm{e} \ldots \ldots \ldots \ldots \ldots \ldots \ldots \ldots \ldots \ldots \ldots \ldots \ldots \ldots . . .(\text { Regresi } 1) \\
& \mathrm{NP}=\alpha+\beta_{2} \mathrm{KK}+\beta_{3} \mathrm{IC}+\mathrm{e} \ldots \ldots \ldots \ldots \ldots \ldots \ldots \ldots \ldots . .(\text { Regresi } 2)
\end{aligned}
$$

Remarks :

$\mathrm{NP}=$ Company Value

IC = Intellectual Capital

KK = Financial Performance

$\mathrm{e}=$ Error Term, presumption error in research .

Path analysis could be conducted to discover direct influence, indirect influence, and total influence size from related variable. Path coefficient represented by output generated. Path coefficient on intervariable relationship referred to as Standardized Coefficient Beta $(\beta)$. Influence coefficient between intellectual capital and performance capital referred to as $\beta 1$. Meanwhile influence coefficient between intellectual capital and company value referred to as $\beta 2$. Influence coefficient of financial performance and company value referred to as $\beta 3$. Path coefficient on direct influence of intellectual on company value through financial performance obtained from multiplication of $\beta 1$ path and $\beta 3$ path. Subsequently, total influence is addition from $\beta 2$ direct influence with direct influence $(\beta 1 \times \beta 3)$.

Therefore, to test whether financial performance evidenced to mediate relationship between intellectual capital and company value, one requirement to meet is that intellectual capital must influence on company value. Therefore first regression is required. If such requirement fulfilled, then second regression could be proceeded to verify such mediation.

\subsubsection{Sobel Test}

Mediation testing could also be carried out using Sobel test. This Sobel Test carried out by testing independent variable indirect influence on dependent variable through intervening variable. Such influence calculated as follow:

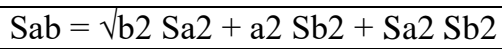


Remarks:

$\mathrm{a}=$ coefficient $\mathrm{a}$

$\mathrm{b}=$ coefficient $\mathrm{b}$

$\mathrm{Sa}=$ standard error of coefficient a

$\mathrm{Sb}=$ standard error of coefficient $\mathrm{b}$

$\mathrm{Sab}=$ standard error size of indirect influence

In order to test indirect influence significance then $t$ value was calculated from ab coefficient with the following formula:

$$
\mathrm{t}=\mathrm{ab} / \mathrm{Sab}
$$

Analysis result would compare $t$ count value. If t count value higher than t-table with significance level 0.10 specifically 1.65 then it could be concluded that such variable mediate relationship between independent variable and dependent variable. Error level 10\% used as intellectual capital...

\section{ANALYSis RESUlt AND Discussion}

This research tested financial performance role as mediation on intellectual capital influence on company value. Data source collection from Indonesian Stock Exchange (BEI). Data in form of several information available on financial statement and annual report of company in 2015-2017 time period. Subject research were company data listed in BEI. Research object were company financial performance, intellectual capital, and company value. Populations used in this research were data from entire company listed in BEI of 2015-2017 period as outlined on Chapter three.

\subsection{Descriptive Statistic}

This sub-chapter would present each research variable, company value as dependent variable, intellectual capital as independent variable, and financial performance as intervening variable. This descriptive statistic aimed to provide description concerning variables used, such as minimum value, maximum value, average value and standard deviation as well on each variable used. Descriptive statistic result on table 4.1 described that:

Table4.1. Descriptive Statistic

\begin{tabular}{|l|c|c|c|c|c|}
\hline & N & Minimum & Maximum & Average & Std. Deviation \\
\hline Company Value & 735 & -0.272336382 & 3735.792915 & 20.471305 & 208.128114 \\
\hline Intellectual Capital & 735 & -2520.662953 & 185.3643827 & 1.814482 & 95.732823 \\
\hline Financial Performance & 735 & -208.4 & 88.70 & 2.470991 & 14.301037 \\
\hline Valid N (listwise) & 735 & & & & \\
\hline
\end{tabular}

Source: Data processing, 2018

Descriptive statistic result for Company Value had maximum value of -0.272 that owned by PT. Bumi Resources in 2015 and for maximum value owned by PT Bank J Trust in 2016 as of 3735. Its average value in 2015-2017 period were 20.471 or 20 times larger than equity book value and evidenced its quite impressive performance.

Descriptive statistic testing result for Intellectual Capital had minimum value of -2520.662 owned by PT. Intraco Penta in 2016 and maximum value owned by PT. Sumber Energi with value of 185.36. its average value in 2015-2017 were 1.814. This range affirms that Intellectual Capital were less practiced in Indonesia.

Descriptive statistic testing result for Financial Performance had maximum value of -208.4 owned by PT Bakrie Telecom in 2017 and maximum value of 88.7 obtained bt PT Dwi Guna Laksana in 2017. Its average value in 2015-2017 showed less satisfying Performance with average value of 2.47

\subsection{Model Analysis}

This research used two stages multiple linear regression test, specifically (1) regression performed to discover independent variable influence of intellectual capital on dependent variable of company value and (2) regression carried out to discover independent variable influence of intellectual capital simultaneously with intervening variable of financial performance on dependent variable of company vale. 
Financial Performance Role as Influence Mediation of Intellectual Capital on Company Value Listed on BEI of 2015-2017 Period

Table4.2. Regression I and II Testing

\begin{tabular}{|l|l|l|l|c|c|}
\hline & \multicolumn{1}{|c|}{ Remarks } & Standard Error & \multicolumn{1}{c|}{ B } & \multicolumn{1}{c|}{ Sig } & $\mathbf{R}^{\mathbf{2}}$ \\
\hline $\begin{array}{l}\text { Regression I } \\
\text { Dependent Variable: Financial Performance }\end{array}$ & Intellectual Capital & .006 & .011 & .043 & .004 \\
\hline $\begin{array}{l}\text { Regression II } \\
\text { Dependent Variable: Company Value }\end{array}$ & Intellectual Capital & .790 & .144 & .069 & .03 \\
\cline { 2 - 6 } & Financial Performance & .531 & 2.370 & .000 & .03 \\
\hline
\end{tabular}

Source: Data processing, 2018

According to above table 4.2, it could be concluded that regression I showed that size coefficient for intellectual capital had positive value of 0.011 which means every 1 rupiah intellectual capital increase generated 0.011 times increase of financial performance. On regression II, size coefficient increase for intellectual capital had positive value of 0.144 which means every 1 rupiah intellectual capital increase generated 0.144 times increase of financial performance, meanwhile size coefficient for financial performance had positive value of 2.37 which means every 1 rupiah increase of financial performance shall highly supported company value increase of 2.37 times.

Determination coefficient (R2) measures how far model ability in describing dependent variable variation. Determination coefficient value ranges from 0 through 1 . Higher determination coefficient represent the higher independent variable that influence dependent variable. According to table 4.2, it could be described that $\mathrm{R} 2$ on second regression was 0.03 which means variation in intellectual capital variable into company value with financial performance mediation was 0.03 and the remaining of 0.97 influenced by other variables outside this research.

\subsection{Hypothesis Verification}

Hypothesis testing had already mentioned in Chapter two, specifically whether financial performance mediate intellectual capital influence on company value, therefore two regressions and one Sobel calculation carried out. The following are the descriptions.

\section{Hypothesis: Financial performance mediate Intellectual Capital influence on company value}

According to table 4.2 intellectual capital coefficient value had positive value of 0.11 with significance of $0.043<0.10(10 \%)$ and positive financial performance value of 0.144 with significance level of $0.000<0.10$. This means that intellectual capital variable and company value through financial performance had significant influence.

From first and second regression testing, to verify that financial performance variable could mediate company value influence or not, then the following sobel calculation taken from www.quantpsy.org performed as follow:

Table4.3. Sobel Test

\begin{tabular}{|c|c|c|c|c|}
\hline \multicolumn{2}{|c|}{ Input } & Test Statistics & Std. Error & p-value \\
\hline $\mathrm{A}$ & 0,011 & & & \\
$\mathrm{~B}$ & 2,370 & \multirow{2}{*}{1,695} & 0,015 & 0,089 \\
\hline $\mathrm{Sa}$ & 0,006 & & & \\
\hline $\mathrm{Sb}$ & 0,531 & & \\
\hline
\end{tabular}

Source: Processing data, 2018

\subsection{Discussion}

Financial performance could mediate intellectual capital influence on company value, it was congruence with hypothesis that it could be stated that hypothesis in this research is accepted $(\mathrm{H}$ is accepted). It is congruence with testing result on first and second regression, then sobel calculation also performed to discover mediation between dependent and independent variable.

This research result able to affirm RBV theory. This theory requires This theory requires company primary role of determining success through ability in transforming its knowledge as idea into knowledge form that could be applied. Knowledge recognition as strategic asset cause primary target to manage, control, rationalize, and even calculate (Sangkala, 2006). In connection with this research, RBV theory manifests in intellectual capital variable that is action from RBV theory through learning, for instance providing attention concerning how company learns, innovates, and diffuses 
technology. This research evidenced that through putting forward learning, innovation, technological diffuse as trademark intellectual capital, company shall more excel in competition reflected on financial performance, that subsequently would influence company value (shares price). Therefore, that PT. Telkom, Tbk and PT. United tractor, Tbk achieved as outlined in chapter 1 are not merely coincidence.

This research result could also confirm signal theory. Basically, signal theory described how should company provides signal into such parties. Signal provided could be in form of company profit information. Such information summarized in financial statement. According to Scott et al (2013:383), information disclosure in financial statement could be used as signal for investors to predict future company performance. Such information disclose also used as signal for decision making basic by parties such as owner, future investors, creditors, supplier, regulator, and government. Therefore, information disclosure in financial statement is crucial. In connection to this research, financial performance that company generate that disclosed in media annual report could provide signal or message to investors and future investors to immediately purchase, sell, or hold company shares. Good financial performance enable numerous interested parties, that shares price (value) of company increase, and vice versa.

\section{SUMMARY}

This research concluded that financial performance could mediate intellectual capital influence on company value. Therefore it supported RBV theory and signal theory. Through putting forward learning, innovation, technological diffusion as trademark intellectual capital, company would excel in competition reflected on financial performance that subsequently would influence company value (shares price). Financial performance that company generate shall be disclosed through media annual report could provide signal or message to investors and future investors to immediately purchase, sell, or hold company shares. Good financial performance enables numerous interested parties, that shares price (value) of company increase, and vice versa.

\section{REFERENCES}

[1] Andyana Putra, I Komang Dedy, Ni Gusti Putu Wirawati. (2013). Pengaruh Kepemilikan Manajerial Terhadap Hubungan Antara Kinerja Dengan Nilai Perusahaan. E-Jurnal Akutansi Universitas Udayana 5.3 (2013) : 639-651.

[2] Anshori, Muslich \& Sri Iswati. (2009). Metodologi Penelitian Kuantitatif. Surabaya : Airlangga University Press (AUP).

[3] Barney, J. B., (1991). Firm resources and sustained competitive advantage, Journal of Management, Vol. 17, pp.99-120.

[4] Besanko, David, Dranove, David, Shanley, Mark, dan Schaefer, Scott. (2013). Economics of Strategy. Sixth Edition. Singapore: John Wiley \& Sons.

[5] Budihardjo, Andreas. (2017). Efektif Berinovasi Meraih Sukses. Jakarta : Prasetiya Mulya Publishing.

[6] Burhan Bungin. (2009). Analisis Penelitian Data Kuantitatif. Jakarta: Raja Grafindo.

[7] Chen, Ming-Chin., Cheng, Shu-Ju., Hwang, Yuhchang. (2005). An Empirical Investigation of the relationship between intellectual capital and firm's market value and financial performance.', Journal of Intellectual Capital, Vol.6, No.2, pp.159-176

[8] Drucker, Peter.F, (1999). Manajemen: Tugas, Tanggung Jawab dan Praktek, Jakarta: PT Gramedia.

[9] Fakhruddin, M dan Hadianto M. Hadianto. (2001). Perangkat dan Model Analisis Investasi di Pasar Modal. Jakarta: Gramedia.

[10] Ghozali, Imam. (2009). “Aplikasi Analisis Multivariate dengan Program SPSS “. Semarang : UNDIP.

[11] Hermuningsih, Sri. (2013). Pengaruh Profitabilitas, Growth Opportunity, Stuktur Modal Terhadap Nilai Perusahaan Pada Perusahaan Publik Di Indonesia. Lecturer at Economic Departemen. Yogyakarta.

[12] Jogiyanto. (2010). Metodologi Penelitian Bisnis. Edisi Pertama. Yogyakarta: BPFE.

[13] Lin, Han, William Tov, dan Lin Qiu. 2014. "Emotional Disclosure on Social Networking sites: The Role of Network Structure and Psychological Needs"., NanyangTechnologyUniversity.Hal:1 http://www3.ntu .edu.sg/home/linqiu/publications/Emotional\%20Disclosure\%20on\%20Social\%20Networking\%20SitesCHB.pdf,

[14] Marisanti. (2012). Analisis Hubungan Profitabilitas Terhadap Pengungkapan Modal Intelektual Capital. Diponegoro Jurnal of accounting. Semarang. 
[15] Moneva JM dan Ortas E. “Corporate Environmental and Financial Performance: a Multivariate Approach. Industrial Management \& Dana System”. 2010. Vol 110. No. 2. pp. 193-210.

[16] Mouritsen, J.,H.T.larsen, dan P.N.Bukh, (2001). Intellectual Capital and The Capable Firm : narrating, Visualising, and Numbering for Managing Knowledge. Accounting, Organizations. And Society, Vol.26, No. $1: 735-762$

[17] Mulyadi. (2014). Sistem Perencanaan dan Pengendalian Manajemen: Sistem Pelipat ganda Kinerja Perusahaan. Yogyakarta : Universitas Gadjah Mada.

[18] Pongpearchan, P. (2016). The Influence of Intellectual Capital on Firm Perfomance of Computer Businesses in Thailand. Medwell Journals, 438-445.

[19] Retno M., Reny Dyah dan Denies Priantinah. (2012). Pengaruh Good Corporate Governance dan Pengungkapan Corporate Social Responsibility Terhadap Nilai Perusahaan (Studi Empiris Pada Perusahaan yang Terdaftar di Bursa Efek Indonesia Periode 2007-2010), Jurnal Nominal, Vol. 1 No. 1

[20] Roslender, R, dan R. Fincham. (2001). Thinking Critically about Intellectuaal Capital Accounting. Accounting, Auditing \& Accountability Journal, Vol. 14, No.4 : 383-339.

[21] Ross et al,.(2010). Fundamental of Corporate Finance (9th Edition). New York : McGraw-Hill

[22] Salvatore, Dominick. (2005). Managerial Economics. Fifth Edition. Singapore: Thomson Learning

[23] Sangkala. (2006). Intellectual CapitalManagement. Jakarta : Yapensi.

[24] Sarumpaet, dkk. (1992). Permainan Besar. Jakarta : Dirjen Dikti Proyek Pembinaan Tenaga Kependudukan

[25] Smithers. Andrew dan Wright. Stephen., (2007), Valuing Wall Street, McGraw Hill.

[26] Soliha, E., dan Taswan. (2002). "Pengaruh Kebijakan Hutang Terhadap Nilai Perusahaan Serta Beberapa Faktor Yang Mempengaruhinya”. Jurnal Bisnis dan Ekonomi. September 2002

[27] Steward, Thomas A. (1998). Intellectual Capital-The New Wealth of Organizations. Diterjemahkan oleh Reza Gunawan. Jakarta : PT Elex Media Komputindo.

[28] Sucipto. (2003). "Penilaian Kinerja Keuangan.” Jurnal Akuntansi. Universitas Sumatra Utara. Medan.

[29] Sucuahi, William dan Jay Mark Cambarihan. (2016). "Influence of Profitability to the Firm Value of Diversified Companies in the Philippines". Accounting and Finance Research. 5 (2). 149-153.

[30] Sudana, I Made. (2011). Manajemen Keuangan Perusahaan. Jakarta: Erlangga.

[31] Sugiyono, (2009), Metode Penelitian Kuantitatif, Kualitatif dan R\&D, Bandung : Alfabeta.

[32] Ulrich, D. (1998). A New Mandate for Human Resources. Harvard Business Review. Vol.1 : 124-134.

[33] William F. Sharpe. (1997). Investasi. Edisi Bahasa Indonesia Jilid 1 \& 2 . Jakarta: Renhallindo.

Citation: Mahanani Putraningrum,. “ Financial Performance Role as Influence Mediation of Intellectual Capital on Company Value Listed on BEI of 2015-2017 Period " International Journal of Managerial Studies and Research (IJMSR), vol 7, no. 3, 2019, pp. 11-21. doi: http://dx.doi.org/10.20431/2349-0349.0703002.

Copyright: (C) 2019 Authors. This is an open-access article distributed under the terms of the Creative Commons Attribution License, which permits unrestricted use, distribution, and reproduction in any medium, provided the original author and source are credited. 